\title{
Anomalías de la efectividad: un modelo matemático utilizado en el voleibol internacional Anomalies in effectiveness: A mathematical model used in international volleyball
}

\author{
*Santiago Calero Morales, *Angie Fernández Lorenzo, **Pedro Antonio García López, *Enrique Chávez Cevallos
}

*Universidad de las Fuerzas Armadas ESPE (Ecuador), **Universidad Técnica de Machala (Ecuador)

\begin{abstract}
Based on the analysis of the mathematical statistical model «Effectiveness», internationally used to process technical-tactical performance in Volleyball, and also to determine its target under the concept «Effectiveness», including its basic characteristics, the paper demonstrates the existence of three mathematical anomalies in the formula. These anomalies are described through examples, including a population-based study that determined that the technical-tactical action Service, Dig and Block have more negative than positive actions, closely related to a fundamental anomaly that causes inaccurate interpretations of reality.

Key words: Effectiveness Model, Volleyball, Technical Tactical Performance, Anomaly
\end{abstract}

Resumen. Partiendo del análisis del modelo matemático de «Efectividad», utilizado internacionalmente para procesar el rendimiento técnico-táctico del Voleibol, y luego de determinar su objetivo atendiendo al concepto «Efectividad», así como sus características básicas, en el artículo se demuestra la existencia de tres anomalías en la fórmula. Dichas anomalías son expuestas a través de ejemplos, donde se incluye un estudio poblacional que determina que los fundamentos técnico-tácticos Saque, Defensa de Campo y Bloqueo presentan más acciones negativas que positivas, aspecto estrechamente relacionado con una anomalía fundamental que provoca interpretaciones inexactas de la realidad.

Palabras clave: Modelo Efectividad, Voleibol, Rendimiento Técnico-Táctico, Anomalía

\section{Introduction}

A model is considered as an abstract representation of some aspects of reality (Gallagher \& Watson 2005; Encarta 2009; González \& Guillén, 2013; Thalheim, 2013). The modelling in sport is usually employed, commonly manifested in the design of exercises that simulate reality game, exercises that make theoretical and practical situations that have happened in the competition, as is the case of technico-tactical complexes or K-1 and K-2 (Fiedler et al 1974; Morales \& Taboada, 2012; Suárez, Rabaz, Fernández, Gil, \& Arroyo, 2017), the typical phases (Fröhner 2004, Martinez 2012) or the simplified situation of the Game (Andux, 2012).

However, the models through exercise are not the only used in the process of management of sports training. The statistics by making physical representations of symbols, simply summarizes phenomena and equations, concepts and theories for studying complex systems (Tormos \& Lova, 2003; Gallagher \& Watson, 2005; Hong, 2013). Therefore, mathematical models are formed by elements that characterize one or more aspects of the reality modelled (Aracil 1983), in order to extract properties and characteristics of the relationships among the elements, which otherwise would remain hidden and illogical.

In the specific case of statistical models to estimate the charge of technical and tactical performance of volleyball, these actions make the technical and tactical variables that evaluate (according to an objective and a specific function), the technical and tactical performance individually and collectively in order to obtain information related to the process of attracting talent, the exploration of opposites, the evaluation of competitive performance, and delivering specialized information to media, researchers, managers, among others (Coleman, 2002; Velasco quoted by Alonso, 2003; Hohmann, Lames \& Letzeier, 2005; Poyato, 2007; Calero, 2009; Silva, Domínguez, Echeverría, Rabaz, \& Arroyo, 2016). Therefore, applied statistics is considered as one of the most important aspects for a coach (Coleman, 2002; Thiess, Tschiene \& Níkel, 2005; Clarke \& Skiba, 2013), both in competitions and in training.

The construction of a mathematical model requires the full employment of concepts, since they classify reality, recalling the objective of the model as a mean to aid in the analysis and understanding of the reality to be measured (Dror, 1986; Tormos \& Lova, 2003; Arsham, 2015).

According to the concept, each processed variable is given a numeric value, making up the design of the formula, a value that must represent

Fecha recepción: 22-04-16. Fecha de aceptación: 14-02-17 Santiago Calero Morales sscalero@espe.edu.ec the real quality of the variable. For that reason, since there are several variables that have significant influence in the performance (according to the technical-tactical actions studied), ones would positively impact in scoring and others would have a negative impact, and also each variable will diverge form the other according to the existing significant differences in relation to the final performance (Calero, 2009-2011). Some mathematic models obtain an approximate description of the phenomenon and in that case it is necessary to check precision if the results are not satisfactory the model should be formulated again using mathematic language(Tang, 2005; Tannery Gore, 2013; Hatano, Hirata, Suzuki y Aihara, 2015).

In Mesquita, Marques \& Maia (2001); Salas, Palou \& Schelling (2004); Oliveira, Mesquita \& Oliveira (2005); Calero (2007-2009); Gil, Del Villar, Moreno, García \& Moreno, (2011); FIVB, (2003-2005), the data of the technical-tactical performance of several techniques and training categories have been tabulated, recording different actions that are usually modelled with Effectiveness and although each paper has its own objective, there are common patterns that undoubtedly typify a technical-tactical action, as the prevalence of negative actions over the positive ones in techniques such as Block, Serve and Dig.

Effectiveness is, according to its definition, «the ability to reach the effect wanted or desired» (RAE, 2015). Effectiveness as a concept is equivalent to reality, certainty, security, validity, warranty (Compact Ocean 2006; Cervantes 2008, Encarta 2009), thus, the primary objective of the model «Effectiveness» is to determine the level of security that has a player or computer when executing technical-tactical actions in the game, this means that if a player gets more points than what he loses, a player is safe, accurate, effective, otherwise it will be a player insecure, not certain, ineffective ${ }^{1}$. Therefore, the variables that represent that concept should symbolize this reality from the mathematical point of view, hence their assessment is in line with that quality.

Effectiveness as a mathematic model uses three significantly influential variables in the final performance (Calero, 2009-2010), it is internationally used by different authors and softwares specialized in applied statistics. In StatTrak for Volleyball, v6.01 (1998); VBSTATS32 V3.2.0E (2002); FIVB (2003-2005); VolleySoft MultiPasport (2005); Mesquita, Marques \& Maia (2001); Sydex Volleyball Stats, (2002); Oliveira, Mesquita \& Oliveira (2005); League Analyzer for Volleyball v3.2.0 (2005); Volleyball Statware v6, (2006) and Quality Stats Volleyball V10.1.0, (2010) ${ }^{2}$ is shown a wide use of that mathematic formula.

The content analysis of the model anticipates statistic anomalies, understanding by anomaly the discrepancy of the model in regard to certain rule or use, in other words, an irregularity. These rules are enumerated in the material and methods epigraph described in Calero (2009); an aspect that causes alterations in the estimation of the technical- 
tactical performance and therefore in the eventual decision-making.

For that reason, the central objective of the paper consists on demonstrating which are those irregularities or anomalies, and how they impact negatively on the process of technical-tactical control of Volleyball, a key factor in the process of sports training management.

\section{Material and Methods}

This concept is conceptualized through the formula or statistical model, available in the following structure:

Model «Effectiveness»

$$
\underset{(j ; e ; c)}{A \neq 0} f=\frac{(A p-A n)}{\mathrm{N}} * 100
$$

Where $i$ is the player and $t$ the technique selected $A P^{t}$ and $A N^{t}$ the number of positive and negative technical-tactical actions in the technique $t$ of the player $i$, respectively, and $N^{t}$ the total of actions in the technique tof the player $i$. Likewise, the total effectiveness of a team or a tournament is defined as the sum of each of the individual effectiveness of every player in the team or the tournament.

In order to show the above mentioned anomalies, some real scoring groups have been analyzed. The first one the Block performance of the $\mathrm{RSA}^{3}$ player in three games of the qualifiers of the IV National Volleyball League (Table 1), obtained by the Effectiveness model.

However, to know the level of incidence equal to or less than zero, obtained by mathematical calculation in the numerator of the formula were analyzed the scores of two national high level championships, in both genders (Tables 4 and 5). For both cases, was processed the population of executed actions (9413 in males and 8683 in females) in the finals of the National Volleyball League IV. Havana 2007, recording 14 games of 14 possible, held on 08.03.2007 to 15.03.2007.

Content Analysis as theoretical methods, values the model «Effectiveness» in accordance with five rules formed to evaluate the process of technico-tactical performance, set by (Calero 2009).

There are:

1. You must determine the proposed function and objective.

2. You should include all variables that influence positively depending on its function and objective.

3. You should have a correct mathematical modelation relating to its function and objective.

4. The measure unity should be the most adequate to the social enviroment it is applied.

5. The numeric value assigned to each variable must correspond to real quality.

Therefore, indicators of contending analysis are in correspondence with those rules, emphasizing, for this study case, rules One and Three.

To register and process the volleyball actions was used the ControlVolei Competencia v1 software, and to tabulate the data Microsoft Excel 2010

\section{Study Variables}

The statistical model «Effectiveness» uses three variables significantly influencing the technico-tactical performance of volleyball. These are:

1. The values of evaluative maximum performance range (positive, Ap) An)

2. The values of evaluative lower-ranking performance (Negative;

3. All other values different from previous issues (causing no losses of these points in absolute terms, AS) joined to all the categories of registered actions.

The first two values can be seen in the numerator, which are computed by a subtraction, or are antagonistic, mathematically creating two variables. The third variable is represented by the sum of all the actions or variables registered in the denominator.
The variables registered (for all the examples will be used the Block actions, except for Tables 4 \& 5) are represented by the following methodology:

- Positive values (Ap): The Block gets the point

- Negative values(An): The block commits a technical foul penalized by the referee, or the lock throws the ball beyond the reach of other players.

- Slash actions (AS): They belong to the rest of the variables that make up the above categories. Example: The ball bounces behind the lock, obtain or not the offensive initiative. For that matter, this variable is creating opportunities for the opponent.

\section{Results}

The statistical model «Effectiveness» presents three anomalies that alter the outcome. These are:

1. Their results show negative rating scale

2. The equivalence between the variables the numerator, creates zero values, not representative of performance in terms of individual comparison.

3. When generating a negative scale, the result is not congruent

Anomaly Number One, «thenegative scales» (shown in the example of Table 1), with locking action made by a player in the first game, provides a result of $-13,33 \%$. This way of presenting quantitative information tends to have drawbacks, for it provides a negative datum, an aspect that infers decreases and contributes to the third and more important anomaly.

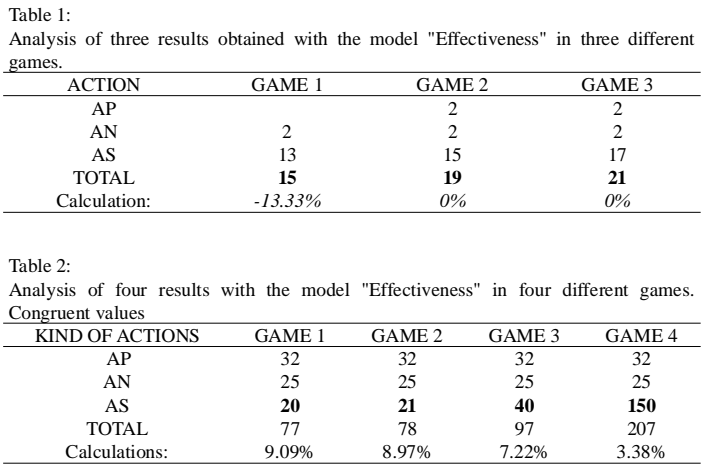

In game number two and three in the table above, you can represent the second anomaly Mathematics, «The equivalence between the variables in the numerator. Here, although the player is regular ${ }^{4}$, the formula shows a figure that would be zero for games two and three. The problem occurs when the amount of opposite variables of the numerator are equal (AP y AN).

The Third Mathematic Anomaly «Non-congruent values» are represented in Table 2, using a hypothetical example for better understanding.

After performing the calculation in the numerator (for all cases equals seven games), and having processed values at each step, the model obtains results that match the athletic performance. In all cases the result expressed numerically decreases progressively.

It corresponds to the real value of a player that will generate the above actions, which is determined based on the concept that the more opportunities you provide to the contrary in its mid-game, the greater the chance of successful adversary, therefore, the effectiveness decreases with increasing the opportunities of the opponent. In every game, the volleyball player gives more opportunities to the rival (20, 21, 40 and 150, respectively; Actions Slash: As) under the same value of the numerator (7), therefore the result will decrease in each game (9.09\%, $8.97 \%, 7.22 \%, 3.38 \%$, respectively). This behavior is seen as consistent or logical, since the model acts positively as expected; prompting him in every game there is a decrease in effectiveness, as it is shown in graphic I 


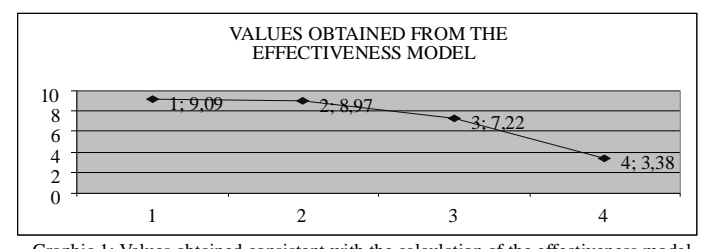

Graphic 1: Values obtained consistent with the calculation of the effectiveness model. Table 3:

Analysis of four results with the model "Effectiveness" in four different games. Incongruent values

\begin{tabular}{ccccc} 
Incongruent values & & & & \\
\hline KIND OF ACTIONS & GAME 1 & GAME 2 & GAME 3 & GAME 4 \\
\hline AP & 25 & 25 & 25 & 25 \\
AN & 32 & 32 & 32 & 32 \\
AS & $\mathbf{2 0}$ & $\mathbf{2 1}$ & $\mathbf{4 0}$ & $\mathbf{1 5 0}$ \\
TOTAL & 77 & 78 & 97 & 207 \\
Calculations: & $-9.09 \%$ & $-8.97 \%$ & $-7.22 \%$ & $-3.38 \%$ \\
\hline
\end{tabular}

Table 3 uses the same numeric values that Table 2, although the values of the Effectiveness model numerator (APand AN) have been inverted to favour understanding, obtaining in all cases the value of -7 (25-32 = -7). By completing the calculations in the formula the values obtained with the model grow as opportunities increase the contrary (20, 21, 40 and 150; Calculation: -9.09\% -8.97\% -7.22\%; -3.38\% respectively). This phenomenon is established where the value of the numerator is in the negative scales, since under this condition, the larger the divisor, will approach zero over the result, and therefore the smaller the numerical value of a negative scale, the higher their mathematical value. Graphic 2 represents graphically the above.

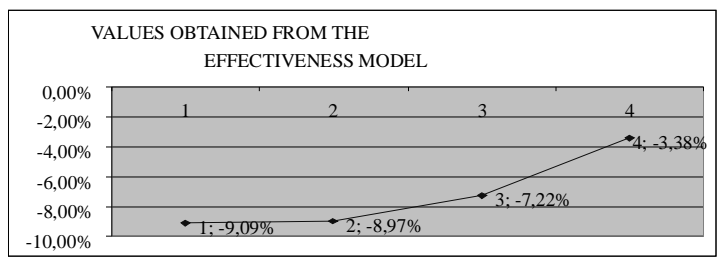

Graphic 2: Non-consistent values obtained with the calculation of the effective model.

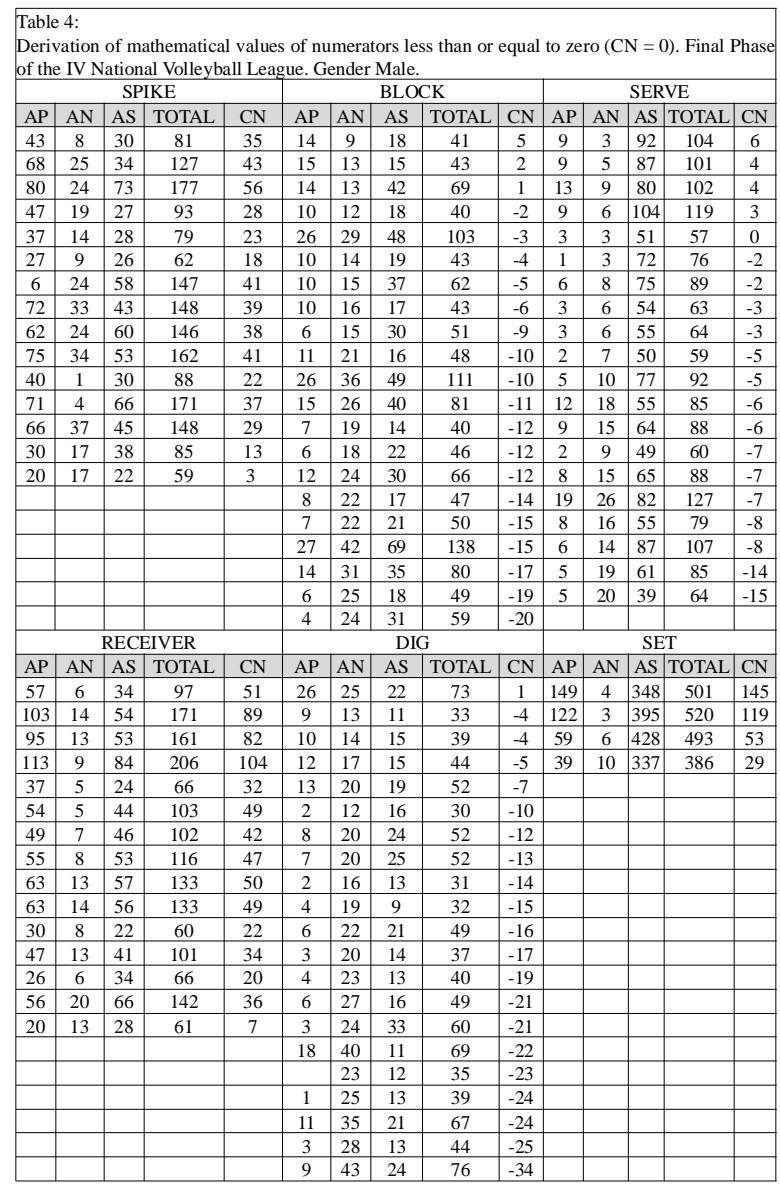

In Table 4, the negative values obtained with the calculation of the numerator are common to the technical-tactical actions Serve, Dig and Block, and non-existent for the rest of the techniques, an aspect that is described in details in Graphic 3.

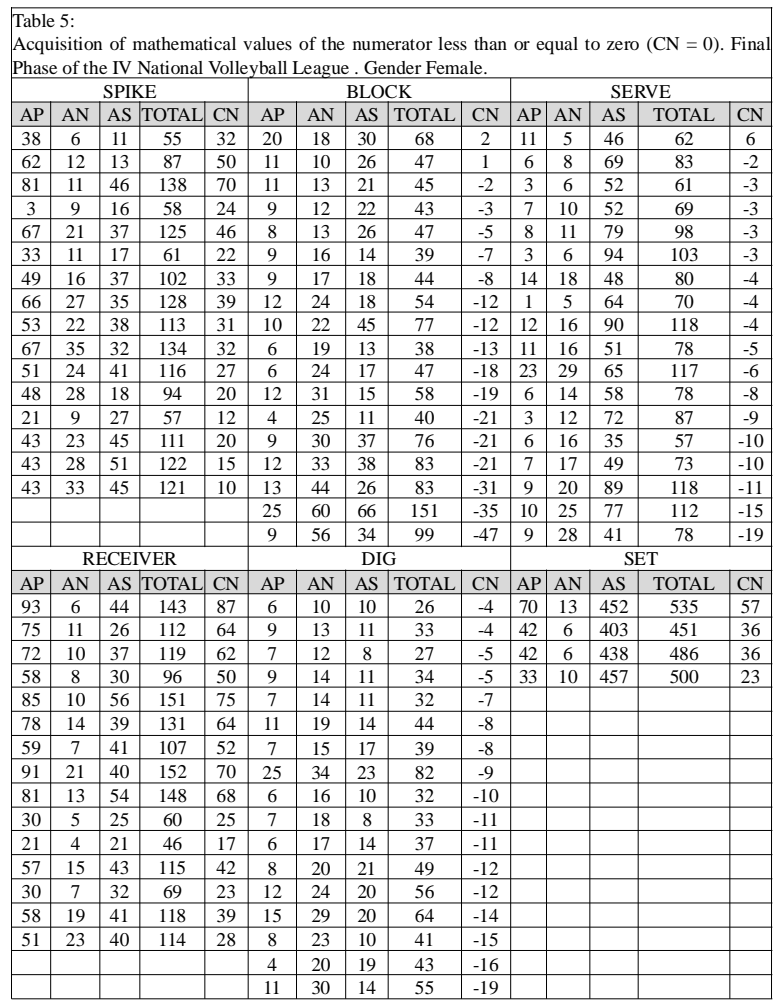

As in table 4 referring to the male gender, Table 5 shows that in the case of female gender, the technical-tactical actions Serve, Defense and Block present a high coincidence of negative values inside thenumerator's calculation.
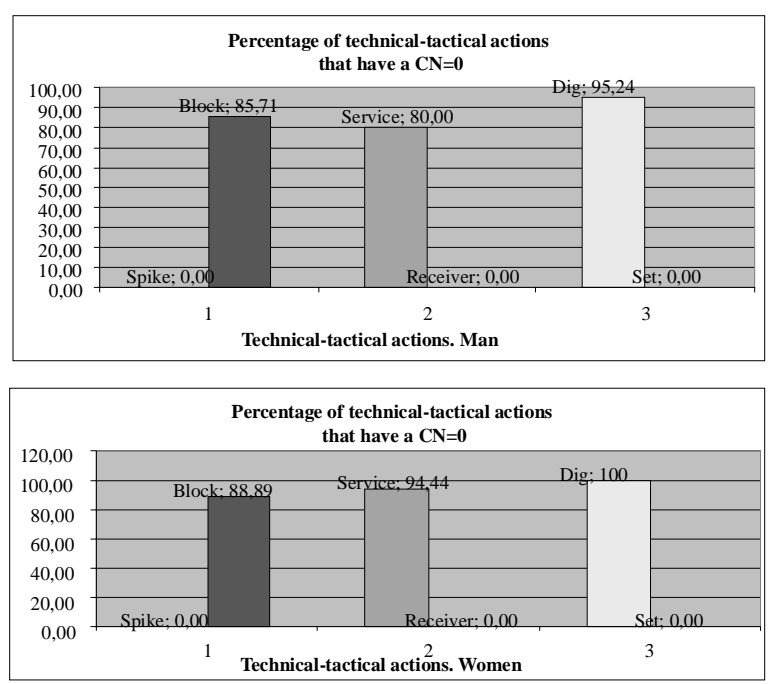

Graphic 3: For hundreds of calculations obtained from the numerator less than or equal to zero $\mathrm{CN}=0$ for each technical-tactical action of volleyball. both genders.

Graphic 3 show the percent incidence of values less and equal to zero, obtained after the calculation of the numerator: $\mathrm{CN} d » 0$, for both genders. That shows that the values have a high percent incidence in the Block, Serve and Dig action(Block: 85.71\% and 88.89\%; Serve: 80.00\% and 94.44\%; Dig: 95.24\% and 100\%, male and female respectively), while such value are not presented in the technical-tactical actions Spike, Receive and Set, respectively (Spike: $0.00 \%$; Receive: $0.00 \%$; Set: 0.00\%, male and female5), according to the individual evaluation of all the regular players that participate in the Finals of the Fourth National 
Volleyball League. The aforementioned shows that the result in the numerator $(\mathrm{CN}<0)$ is common in high performance volleyball.

\section{Discussion}

Since the Effectiveness statistic model is internationally and functional in several research papers and softwares of applied statistics to Volleyball such as StatTrak for Volleyball, v6.01 (1998); Mesquita et als, (2001); Sydex Volleyball Stats(2002); VBSTATS32 V3.2.0E,(2002); FIVB, (2003-2005); VolleySoft MultiPasport (2005); Oliveira et als., (2005); LeagueAnalyzer for Volleyball v3.2.0(2005); Volleyball Statware v6, (2006) y Quality Stats Volleyball V10.1.0, (2010), among others, the reliability of the mathematic instrument should positively respond under any condition.

However, when the result of the numerator equals zero, the numerical values processed, regardless of the amount and importance, cause equal results (Table 1: game 2 and 3: 0 percent respectively). Another real example is available in Table 4: in the Serve action, whichis colored in blue, and in the ranking best block, best serve and best dig of the World Championship 2011(FIVB, 2011a,b,c), which demonstrates that it happens regularly.

In Calero (2009) was studied the Finals of the Volleyball World League held in Moscow, Russia, and it was defined that the probability to lose one point after an AS action in Block is 47,78 percent, and the probability to score a point 25,06 percent (Difference: 22,72 percentage points more in favour of losing a point); for which the AS Blocking actions give the opponent more advantages. Therefore, the AS action should be statistically interpreted as a variable that reduces the final value obtained by the Effectiveness model. The Table 1 predicts estimation errors of the technical-tactical performance of the Block, concerning the RSA player, who in games 2 and 3 has the same result (0 percent) even performing different actions AS (15 and 17 respectively) under the same numerator value. That indicates that the model equals performance when actually had substantial variations in the actions. Each significantly influential action will have more or less probabilities of losing or winning a point, as it is the case of the setter demonstrated in Calero (2009, 2011), and the rest of the technical-tactical action. Therefore, as there are differences in then Slash (AS) actions, there must be numerical differences in the final result of the equation.

This player, if compared to one that has never played, seemed to have the same numeric value (0). Then, reality affirms that not playing equals doing nothing in practice, and having two positive actions (AP), two negative (AN) and 15 Slash (AS) (Table 1) equals influential values in higher or lesser numbers for the technical-tactical performance. That causes two problems for the coach, the first situation would be the impossibility of comparing a regular player and a bench one (both would have a numeric value of zero); the second situation will be related to the competitive ranking, since an Aplayer with a numeric value of 0 will mathematically overcome every player with more negative than positive actions, although the A player as an excessively higher amount of Slash (SA) actions; therefore, the coach will make a mistaken analysis of the individual performances, which would cause taking wrong decisions.

The previous anomaly derives from the possibility that the technical-tactical variables have equal negative and positive actions, since theEffectiveness model is able to generatenegative values (anomaly 1).

The error of the Effectiveness model negatively increases the estimation of the technical-tactical performance by presenting more negative actions than positive ones (Serve, Dig, Block), an common aspect demonstrated in tables 4 and 5 and represented in graphic 3 . That characteristic in the action of the technical-tactical actions previously described have been widely corroborated by other sources, such as Mesquita, Marques \& Maia (2001); Salas, Palou \& Schelling (2004); Oliveira, Mesquita \& Oliveira (2005); Calero, (2009); Gil et als (2011); FIVB (2003, 2011a,b,c), an inconvenient increased in younger categories (Calero, 2007), for which the research carried out from the model analyzed, as the one made in Block by Oliveira et als. (2005), distort the result expected and therefore the data is wrongly interpreted, taking into account that the more the technical-tactical opportunities given to the rival, the more probabilities of losing a point, and therefore the final value should decrease in the final Effectiveness equation.

However, Effectiveness under the condition $\mathrm{CN}<0$ raises the final value as the AS actions increase, or increases the value as the technicaltactical opportunities given to the rival increase. This contradiction causes uncertainty in the estimation of the technical-tactical performance, coinciding with the affirmation made by Tang (2005) that models with similar imprecision should be reformulated. Therefore, if the Effectiveness model is used, the rankings of the Block, Serve and Dig actions will distort reality, since ever AS action will wrongly increase the numeric performance of a player, when if should reduce it.

The Effectiveness statistic model as it generates equal or lesser values than zero after the calculation of the numerator (Anomaly 1 and 2), creates inconsistent values (Anomaly 3). The three anomalies previously noted do not fulfil the third rule for processing the technicaltactical performance; since it has a wrong mathematical modelling in relation with the objective pursued (determine effectiveness). That implies that the model does not determines correctly the goal of the authors (Rule number 1 ) when the $\mathrm{CN}<0$ condition is present, having a negative influence in the estimation of the individual and collective performance of the technical-tactical actions of volleyball, with emphasis in Serve, Dig and Block.

That allows affirming that the Effectiveness statistic model, after calculating the numerator and presenting the condition $\mathrm{CN}<0$, shows a false fulfilment of the goal, causing three mathematic anomalies that imply false interpretations of the reality.

\section{Conclusions}

The above can generally conclude that:Effectiveness in the statistical model is identified under the condition $\mathrm{CN}<0$, obtained in the processing of the variables in the numerator of the formula referenced, three anomalies that adversely affect the performance estimation of technicaltactical Volleyball, causing certain false conditions and interpretations of the final performance. For that reason, the use of the Effectiveness statistical model should be applied on those technical-tactical actions with more positive actions than negative ones (Spike, Receive and Set), while its application must be excluded from those fundamentals that regularly obtain more negative actions than positive ones (Block, Dig, Serve).

\section{Autor Notes}

1. In the paper the word Ineffective is considered an antonym of Effective

2. Not all authors have the same organization for the previously described model, although the structure is similar.

3. By ethical reasons, the name of the player is omitted.

4. A regular player is that who plays and participates in several actions of the game, meaning that the team depends on his performance.

5. Although in the competitions analyzed the regular players had no negative values higher than the positive ones ( $\mathrm{CNd}$ »0), in the case of Spike, Receive and Set, other national competitions have had them, especially in younger categories, according to studies made in other competitions available in Calero (2007-2009).

\section{Acknowledgments}

To the Programa Prometeo de la Secretaría Nacional de Educación Superior, Ciencia, Tecnología e Innovación de la República del Ecuador

\section{References}

Ace Volleyball Analyzer v7. (2009). Dimensional Software Inc. USA 
Alonso, J. (2003). Resumen de las conferencias impartidas en el Clinic International Data Project. Análisis y estadística del Voleibol moderno: La planificación, Estudio del adversario, duranteel partido y aplicación al entrenamiento. Bolonia, Italia.

Andux, C. (2012). Las situaciones simplificadas del juego: Modelos de enseñanza del Voleibol. Conferencia especializada impartida en laEspecialidad de postgrado «Voleibol para el alto rendimiento». Escuela Nacional de Voleibol, Federación Cubana de Voleibol y Universidad de Ciencias de la Cultura Física y el Deporte «Manuel Fajardo», Enero, La Habana.

Aracil, J. (1983). Introducción a la dinámica de sistemas. Ed. Alianza. Madrid. España.pp.18

Arsham, H. (2015). Probabilistic Modeling Process: Decision analysis. Consultado el día 10 de Enero de 2016 de la Web http:/home.ubalt.edu/ntsbarsh/ opre640a/partIX.htm

Calero, S. (2007). Estadística aplicada para profesionales del Voleibol. Curso impartido en la Facultad de Cultura Física «Nancy Uranga Romagoza» de Pinar del Río. Federación Cubana de Voleibol. Pinar del Río, Cuba.

Calero, S. (2009). Sistema de registro y procesamiento del rendimiento técnicotáctico para el voleibol de alto nivel. Tesis en opción al grado científico de doctor en ciencias de la Cultura Física. Departamento de Juegos Deportivos. Universidad de Ciencias de la Cultura Física y el Deporte, La Habana, Cuba. pp. 14-36, 66, 205-232, 324-330

Calero, S. (2010). Las fórmulas estadísticas clásicas para procesar rendimiento técnico-táctico en el Voleibol. Lecturas: Educación Física y Deportes, Revista Digital-Buenos Aires - Año 15- No 144 - Mayo. http://www.efdeportes.com/ efd144/rendimiento-tecnico-tactico-del-voleibol.htm

Calero, S. (2011). Variables significativamente influyentes en el rendimiento de pasador de voleibol. Revista Internacional de Medicina y Ciencias de laActividad Física y el Deporte vol. 11 (42) pp. 347-361. Http://cdeporte.rediris.es/ revista/revista42/artvariables214.htm

Clarke, D. C., \& Skiba, P. F. (2013). Rationale and resources for teaching the mathematical modeling of athletic training and performance. Advances in physiology education, 37(2), 134-152.

Compact Océano (2006). Diccionario de Sinónimos y Antónimos. Barcelona, España., Grupo Editorial S.A Océano, pp. 198.

Dror, Y. (1986). Enfrentando el futuro. Editorial Fondo de Cultura Económica México.pp. 33-35

FIVB (2003). CD-ROM- Top Volley: Men’s Game. Techniques and Tactics. Lausanne, Switzerland

FIVB(2005). VIS Staff Guidelines. Evaluation Criteria. Lausanne, Switzerland.

FIVB (2011a). World League 2011. Fédération Internationale de Volleyball. www.fivb.com, Best Blockers: Consultado el día 12 de Enero de 2016 de la WorldWideWeb: http://www.fivb.org/EN/Volleyball/Competitions/ WorldLeague/2011/Best_Players.asp?Tourn=WL2010\&Skill=BLO

FIVB (2011b). World League 2011. Fédération Internationale de Volleyball. www.fivb.com, Best Servers: Consultado el día 12 de Enero de 2016 de la World WideWeb: http://www.fivb.org/EN/Volleyball/Competitions/ WorldLeague/2011/Best_Players.asp?Tourn=WL2010\&Skill=SRV

FIVB (2011c). World League 2011. Fédération Internationale de Volleyball. www.fivb.com, Best Diggers: Consultado el día 12 de Enero de 2016 de la World WideWeb: http://www.fivb.org/EN/Volleyball/Competitions/ WorldLeague/2011/Best_Players.asp?Tourn=WL2010\&Skill=DIG

Fröhner, B. (2004). Voleibol: Juegos para el entrenamiento. Buenos aires. Editorial Stadium. Argentina. pp. 19-40

Gallagher, C. y Watson, H. (2005). Métodos cuantitativos para la toma de decisiones en administración. Editorial Félix Varela. La Habana, Cuba. pp.15-20

Gil Arias, A.; Del Villar Álvarez, F.; Moreno Domínguez, A.; García González, L. y Moreno Arroyo, M.P.(2011). Análisis de la eficacia del saque de voleibol en categoría de formación. Revista Internacional de Medicina y Ciencias de la ActividadFísica y el Deportevol. 11(44)pp. 728-730. Http://cdeporte.rediris.es/ revista/revista44/artanalisis242.htm

González, R. S., \& Guillén, J. P. (2013). Consideraciones Teóricas en el Diseño de Modelos. Interacción y Perspectiva, 3(1)

Hatano, T., Hirata, Y., Suzuki, H., \& Aihara, K. (2015). Comparison between mathematical models of intermittent androgen suppression for prostate cancer. Journal of theoretical biology, 366, 33-45.

Hohmann, A., Lames, M. y Letzeier, M, (2005). Introducción a las ciencias del entrenamiento. Paidotribo. Pp 51-62

Hong, F. T. (2013). The role of pattern recognition in creative problem solving: A case study in search of new mathematics for biology. Progress in biophysics and molecular biology, 113(1), 181-215.

LeagueAnalyzer for Volleyball v3.2.0 (2005). Analyser Software Inc. USA

Martínez, M.(2012). Entrenamiento avanzado a partir de las fases típicas del voleibol. Modulo de Entrenamiento Avanzado; Especialidad de Postgrado «Voleibol para elAlto Rendimiento». Escuela Cubana de Voleibol, Federación Cubana de Voleibol y Universidad de Ciencias de la Cultura Física y el Deporte «Manue
Fajardo», La Habana; Cuba.

Mesquita, I., Marques, A., y Maia, J. (2001).A relação entre a eficiência e a eficácia no domínio das habilidades técnicas em Voleibol. Revista Portuguesa de Ciências do Desporto, vol. 1, n 3. Faculdade de Ciências do Desporto e de Educação Física Universidade do Porto. Portugal.pp.33-39

Morales, S. C., \& Taboada, C. S. (2012). Guía operativa sobre metodología observacional para registrar rendimiento técnico-táctico en el voleibol de alto nivel. Lecturas: educación física y deportes, (167), 5-21. http:// www.efdeportes.com/efd167/metodologia-observacional-en-el-voleibol.htm

Morales, S. C., Taboada, C. S., \& Lorenzo,A. F.(2016a). Determination of the scale of values for the offensive technical and tactical performance of Cuban volleyball. PartI.Lecturas: educaciónfísicay deportes, (217), 21.http://www.efdeportes.com/ efd217/scale-of-values-of-cuban-volleyball-1.htm

Morales, S. C., Taboada, C. S., \& Lorenzo, A. F. (2016b). Determination of the scale of values for the offensive technical and tactical performance of Cuban volleyball. Part II, the end. Lecturas: educación física y deportes, (218), 21. http://www.efdeportes.com/efd218/scale-of-values-of-cuban-volleyball-2.htm

Oliveira, R., Mesquita, I. y Oliveira, M. (2005). Caracterização da eficácia do bloco no Voleibol de elevado rendimento competitivo. Estudo aplicado em equipas masculinas participantes na Liga Mundial 2003. Lecturas: educación física y deportes, Buenos Aires - Año 10 - N 84 - Mayo 2005. http:// www.efdeportes.com/efd84/voleibol.htm

Poyato, N.J. (1969). Notes on German statistics of 1969, taught in Cuba by Dieter Ground(Without publishing). Cuban Volleyball Federation, La Havana, Cuba

Poyato, N.J. (2007). The volleyball scouting worldwide. I National Course on performancemonitoring in Volleyball and beach volleyball. .Volleyball National School of International School of Physical Education and Sports, May 26 to June 2, 2007. La Havana, Cuba

Quality Stats Volleyball V10.1.0 (2010). HandBooks. Qualitystats Company. USA

RAE(2015). Definición de «Efectividad». Real Academia Española. Extraído el 23 de Enero del 2016 de la Web: http://dle.rae.es/?w=efectividad

Salas, C., Palou, N., y Schelling, X. (2004).Análisis de las acciones ataque-bloqueo en el Voleibol Masculino. Lecturas: educación física y deportes, Revista Digital - Buenos Aires - Año 10 - N 70. Marzo. http://www.efdeportes.com/efd70/ voley.htm

Silva, J. G., Domínguez, A. M., Echeverría, C. F., Rabaz, F. C., \& Arroyo, M. P. M. (2016).Asociación entre variables de la recepción y la zona de envío de la colocación en voleibol, en etapas de formación. Retos: nuevas tendencias en educación física, deporte y recreación,(29), 149-152.

StatTrak for Volleyball, v6.01 (1998). All-Pro Software Inc., Madison. USA

Suárez, M. C., Rabaz, F. C., Fernández-Echeverría, C., Gil-Arias,A., \& Arroyo, M. P. M. (2017). Toma de decisiones y rendimiento en las acciones de juego en voleibol, en sets con diferentes resultados (Decision-making and performancein game actions in volleyball, in sets with differents results). Retos: nuevas tendencias en educación física, deporte y recreación,(31), 28-33.

Sydex Volleyball Stats (2002). Sydex Computer System. Designer and produced by: Michael Phillips y Melanie Bolt. USA.

Tang, S. (2005). Matemáticas para administración y economía. Thomson. USA.pp.145

Tanner, R., \& Gore, C. (2013). Physiological tests for elite athletes. USA. Human Kinetics.

Thalheim, B. (2013, June). The conception of the model. In Business Information Systems (pp. 113-124). Springer Berlin Heidelberg.

Thiess, G, Tschiene, Py Nickel, H. (2005).Teoría y metodología de la competición deportiva. Barcelona, España, Editorial Paidotribo, pp 196-210

Tormos, P. y Lova,A. (2003). Investigación operativa para ingenieros. Universidad Politécnica de Valencia, España, pp 33-40

VBSTATS32 V3.2.0e(2002). Park Enterprises, Nebraska, USA.

Volleyball Statware v6 (2006). Team Statware Statistics software for Volleyball User Manual. Digital Scout. West Henderson Road Columbus. USA

VolleySoft MultiPasport (2005). HandBooks. France. Extraído el 5 de Julio del 2012 desdehttp://perso.wanadoo.fr/caribean.voleibol/page3.htm.

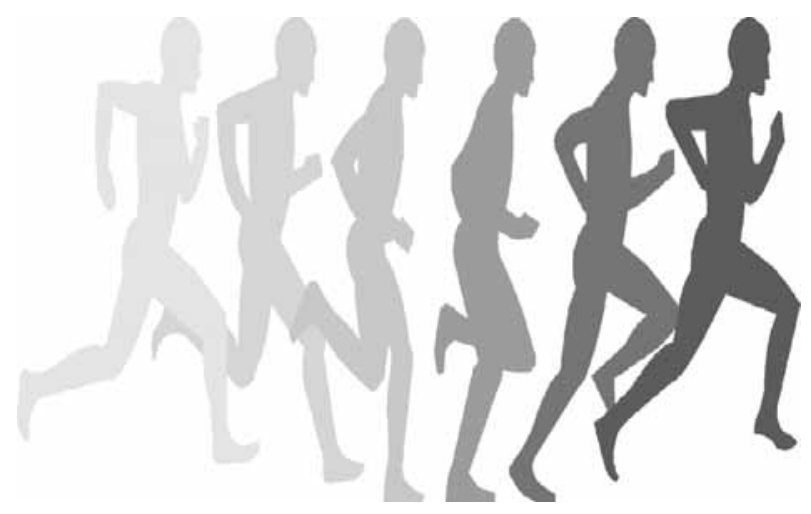

